Oleksandra Zmiyenko

\title{
THE EU: POWER(LESS) IN STATELESSNESS? THE CASE OF THE BALTIC STATES
}

Despite still being an emergent research area, statelessness has come to attract growing attention both from academics and among policy-makers. So far, this legal vacuum, that represents a violation of the right to nationality, and has consistently been perceived through the prism of other human rights-related issues. To avoid oversight, statelessness needs to be perceived as a distinct phenomenon and to be addressed as such on the policy-making agenda. The European Union has two overt examples of statelessness among its Member States: Latvia and Estonia. In these post-Soviet countries, statelessness emerged in conjunction with debates over state continuity and state succession. The main question to be asked is to what extent does the EU have leverage when it comes to addressing the problem of statelessness? In its Member States, where questions of citizenship fall under the national competences, the EU influence in this regard seems limited, which is even more apparent outside of the EU. However, for the countries with 'European aspirations', there are different ways to have an impact: either before or after accession. Given its terminological ambiguities and that possible solutions to statelessness may be offered from a diverse range of academic fields, the research methodology of this study is interdisciplinary: from legal to historical analysis. While conditionality imposed on the aspiring members has a clear outcome in terms of legislation changes, once these states have acceded, the EU tends to have less influence. Conditionality might serve as a possibility to address statelessness among the countries with 'European aspirations', while increased pressure to fulfil international obligations may be crucial in dealing with Member States.

Keywords: statelessness, post-Soviet, Latvia, Estonia, the European Union

DOI: 10.17323/727-0634-2018-16-4-677-690

Oleksandra Zmiyenko - MA Law, Jagiellonian University; European Interdisciplinary Studies College of Europe; Academic Assistant at the College of Europe, EU International Relations Department, Bruges, Belgium. Email: Oleksandra.zmiyenko@coleurope.eu 
Quod non est in actis, non est in mundo (what is not kept in records does not exist) is a Latin phrase that may be relevant to the situation of stateless persons. Statelessness in modern Europe seems to be a relatively invisible issue for policy-makers, in spite of the fact that there are more than fifteen million people worldwide who do not possess any citizenship (ISI 2014: 11). Statelessness is a phenomenon that attracts scholarly interest (Manly, Van Waas 2014) and may even be perceived as a topic for a degree programme. Notwithstanding this, it has to be seen as a distinct human rights issue (Foster, Lambert 2016).

De jure statelessness is defined by international law. Its juxtaposition with the notion of de facto statelessness contributes to the lack of a common definition and affects a possibility to create a comprehensive normative framework for addressing statelessness (Tucker 2014:277). The emergence of research institutes, such as the Institute on Statelessness and Inclusion and Melbourne Law School's Peter McMullin Centre on Statelessness imply there is a growing academic discourse on the issue.

In the European Union, despite alleged differences in root causes of the statelessness, there might be a common institutional way to address it. However, the main question remains as to what extent does the EU have leverage on the problem of statelessness both internally and externally? The EU is more than a major economic actor, it is aspiring to be perceived as a normative power. Ian Manners defines this as the 'ability to shape what is "normal" in international relations' (Manners 2002:236). This includes trying to advance protection and freedoms to its own citizens and to exercise its soft power worldwide (Nye 2004:5), and places human rights as the objective of the external action (European Parliament 2018).

EU member states noticeably affected by the issue of statelessness are mostly those who joined in the most significant enlargement. In some ways this is a contentious statement in the aftermath of the so-called refugee crisis, given that its impact on numbers of potentially stateless persons residing on the territory of the EU is yet to be estimated. Nevertheless, operating with measurable data as of 2018, it may be argued that Latvia and Estonia still lead in the number of stateless persons. Both countries have demonstrated legislative innovation creating a sui generis legal status for its endemic statelessness. Similar geopolitical fluctuations in the beginning of last decade of $20^{\text {th }}$ century brought other examples of statelessness in the countries that became the EU Member States, such as Czechia, where conditions for the expulsion of a Roma minority were created (Cahn 2012:304) or Slovenia, where human rights violations toward the Erased went unnoticeable in EU integration process (Vrbek 2015). While assessing the EU conditionality, tracking legislative amendments would not give a full picture of real socio-political change that the EU is allegedly aiming to produce (Sasse 2008: 855).

This paper is a part of a larger policy-oriented research project, which explains the ways of addressing statelessness by the EU as an external actor, 
assesses the possible roles of the EU institutions and includes a broader range of examples (Zmiyenko 2017). The paper focuses on both legal and historical approaches, while describing the pre- and post-accession periods in the two chosen post-Soviet states - Latvia and Estonia - through prism of human rights protection and the 'Europeanisation of law' (Snyder 2000). It also examines the differences in the EU leverage on problem of statelessness before and after the accession, shedding light on the external and internal dimension of possible policy responses. The outlined interdisciplinary perspective provides insight on possibilities to apply or to avoid applying the same patterns that were used for the former non-EU states.

\section{The root causes of statelessness in the EU post-Soviet countries}

The fall of the Berlin Wall contributed to understanding of the state continuity of the Baltic States, which was indicated by the lack of international recognition of annexation of Latvia, Estonia and Lithuania in 1940, while de facto control over territories was seized by the Soviet Union. Sovereignty restoration in 1991 resulted either in renewing membership in the international organizations, or gaining a new membership status, which still may be regarded as a new chapter of a state-building. Like the other newly independent countries in Central and Eastern Europe and Western Balkans, the Baltic States experienced challenges related to shaping their regained statehood. Given the changed demographic context due to the influence of Soviet rule, social and ethnic differences became more sensitive after the dissolution of the previous system. Arguably, the legislation that emerged in the period of sharp changes, especially the one related to citizenship, was instrumentalised as a form of 'ethnic engineering' (Costamagna 2013: 40) and had further impact on the image of the young Baltic democracies.

\section{Case study: the Baltic States}

The demographic changes that occurred during the period of Soviet rule in the Baltic States were not equivalent for all the three countries. Policies of collectivization and industrialization attracted a new labour force from the other Soviet republics. Migration was encouraged by the government and encouraged by the higher living standards in the Baltic States (Simonian 2004: 69-70). Moreover, the ethnic composition of the Baltic States was disturbed by Stalinist repressions. Persecuted persons, who were not capable of seeking asylum abroad, were subjected to execution or deportation within the Soviet Union. This led to '100,000 ethnic Estonians, 169,000 ethnic Latvians, and 267,000 Lithuanians' being removed from census date in the twenty-five years following 1934 (Gelazis 2004:226). In the first years of regained independence, the percentage of the 'indigenous' population in the Baltic States was lower than in 
the inter-war period. It mostly affected Latvia, where the number decreased from $75.5 \%$ to $55.1 \%$ and Estonia, where the $88 \%$ of ethnic Estonians dropped to $61.5 \%$, whereas Lithuania's ethnic composition remained comparably consistent - approximately $80 \%$ of ethnic Lithuanians both in middle of 1930 s and in 1989 (Gelazis 2004:228). These demographic differences might explain the contrast in approaches to sovereignty, national minorities and deriving citizenship policies. The Lithuanian law on citizenship, adopted before the fall of the Berlin Wall ${ }^{1}$, was inclusive in principle and led to acquisition of nationality ${ }^{2}$ by $90 \%$ of residents by the end of 1991 (Gelazis 2004:227). The criteria for naturalization according to the consecutive law on citizenship did not differ much from two remaining Baltic States and included time of residence (above 10 years) on the territory of Lithuania, declaration of the stable sources of income, knowledge of language, history and Constitution. In Lithuania, thus, statelessness did not emerge to the extent it did in Latvia and Estonia.

In Latvia, where according to Human Rights Watch, 'statelessness remains a key concern' (Human Rights Watch 2017:275), the problem of a legal vacuum emerged on the margin between de facto state succession and de jure state continuity. State continuity presupposes that the incorporation of the territory of Latvia into the USSR was not internationally recognized; however, the factual establishment of Soviet rule was impossible to negate. The high degree of the 'russification' of Latvia was indisputable and remained in the centre of a political, and further legislative debate in the first years of regained independence (Muiznieks et al. 2013:294).

The restoration of the Constitution from 1922 was one of the elements emphasising the adherence to the assumption of state continuity. The document was in a certain way outdated, given the fact that it did not contain modern legislative developments, such as references to human rights (Gelazis 2004:228). Following the same logic, the 1919 law on citizenship was reintroduced and other legislative developments, such voiding Soviet legislation, led to a new restrictive policy on citizenship. Only those who were nationals of independent Latvia (before 1940) and their descendants ${ }^{3}$ could automatically 'regain' citizenship of re-established state in 1991. Consequently, $64 \%$ of permanent residents were registered as citizens, while the rest of population became stateless (Gelazis 2004:228). As Sanja Vrbek concluded with reference to Helen Morris (Morris 2003:1-37), 'the fact that around 30\% of resident population was deprived of automatic citizenship was not seen as problematic by the international community' (Vrbek 2015:310). Arguably, de novo inde-

\footnotetext{
${ }^{1}$ The law on citizenship was adopted on 3 of November 1989, before the formal declaration of independence.

${ }^{2}$ Despite differences between two notions in the Soviet context, in the present paper citizenship and nationality are used synonymously.

${ }^{3}$ Further referred in this paper as 'ethnic Latvians', and 'ethnic Estonians' by analogy.
} 
pendent Latvia received a democratically elected national parliament composed of predominantly ethnic Latvians because stateless persons were not able to vote. Lacking voting rights, however, was not the only concern of stateless persons: Latvian Human Rights Committee (2013) published a list of differences in rights between Latvian citizens and non-citizens of Latvia that contained 142 items.

The status of those who were not able to acquire citizenship within the 'windows system'1 of demanding naturalization procedures was not defined up to 1995. In-between legislative acts aiming to fill the legal vacuum (Latvian Human Rights Committee 2013: 2) were followed by the Law 'On the Status of those Former U. S.S.R. Citizens who do not have the Citizenship of Latvia or that of any Other State' (adopted by the Saiema on 12 April 1995). It created a new legal status - 'non-citizen', which aimed to address the issue of statelessness. Without an attempt to adjust naturalization requirements to the needs of emerging human crisis, the law invented a creative way to approach the issue. 'Non-citizens', were defined as 'not citizens of Latvia' but to a certain extent not stateless either. A decade later, 'granting of the status of a non-citizen to a certain group of persons' was defined by the Constitutional Court of Latvia as 'the result of a complicated political compromise' (Case No. 2010-20-0106, par. 13). Developed through an extensive jurisprudence (e. g. the Judgement of the Constitutional Court in a landmark case regarding non-citizens, No.200415-0106, 7 March 2005) the rights such as diplomatic protection and right to reside (Krūma 2014:379) drew a line between stateless persons and non-citizens. The Constitutional Court reaffirmed that 'Latvia undertakes certain liabilities with regard to [non-citizens]' (Krūma 2014:380; Case No. 2004-150106). These affirmations appeared in rulings of the courts of different instances and asserted that 'the Republic of Latvia has recognized its jurisdiction over non-citizens and that a non-citizen of Latvia is approximated to the status of a citizen in terms of his or her rights' (Krūma 2014:371) and that 'the connection of a non-citizen with the Republic of Latvia is closer than that of a stateless person or a foreign national' (Krūma 2014:374).

The status of non-citizens in Latvia was meant to serve as a temporary means of resolving the issue of statelessness. Numerous examples, however, confirmed that not only the very existence of this status allowed for the lack of a sufficient reform of naturalization process, but also removed any incentive to go through naturalization procedures (Krūma 2014:377-398). Jurisprudence on diverse cases of non-citizens and modus operandi of the courts demonstrate that the 'temporality' of status is a fiction (Krūma 2014: 377-398), observing also the continuous registration of the children as non-citizens. In other words, this unique legal status not only left the problem unresolved, but also contributed to its own continuity.

\footnotetext{
${ }^{1}$ Limits imposed to start a naturalisation procedure according to the year of birth.
} 
Circumstances that led to emerging of statelessness Estonia were comparable to the ones of Latvia, yet policy responses to the problem were different. One of the landmarks of the restoration of Estonian independence was the $6^{\text {th }}$ of November 1992 adoption of the decree by the Supreme Council of the Republic of Estonia on the application of the Law on Citizenship which was proclaimed by the Republic of Estonia in 1938 (Parliament of Estonia 2016). Similar to Latvian legislation, it provided a possibility of acquisition of citizenship only by pre-war Estonians and their descendants. Amended in 1995 Citizenship Law and its following amendment provisions ruled on strict naturalization procedures for non-ethnic ${ }^{1}$ Estonians (Vetik 2011:231-234). In nearly two decades the amount of naturalized persons comprised 150,000 (Vetik 2011:233) whereas 100,000 persons remained stateless.

Legislation on stateless persons did not create a separate legal status of non-citizens. Instead, in the Law on Aliens there was a reference to 'aliens' (Vetik 2011:235) - the notion related equally to nationals of foreign states and so-called 'individuals with undetermined citizenship' (määratlemata kodakondsusega isikud). The status per se was not defined in the legislation; it was used, however, to replace reference to stateless persons (European Network on Statelessness 2015: 1). Aliens' passports (so-called 'grey passports') served as temporary travel documents. In 1994 the first ones were issued for a single-use trips. Then, they evolved into a document that was valid for two years (Miljan 2015:38). Given the progress in naturalization procedures, acquisition of citizenship in other countries, e.g. the Russian Federation and the prospect of the European integration, the amount of aliens' passports dropped from 190,190 in 1994 to 58,643 in 2003 (Miljan 2015: 39). In 2013, nearly a decade after Estonia became a member of the European Union; the amount of aliens' passports issued equalled 9,703 (European Network on Statelessness 2015: 1).

Eradication of de jure statelessness through naturalisation process requires understanding of its challenges beyond the legal aspects. People who were deprived of nationality by the circumstances related to rebuilding of the statehood of the country of their residence, eventually got the choice to apply for citizenship. Their decisions were not solely affirmative. Narratives of stateless persons in Estonia included reasoning based on factors beyond the practical convenience. Remaining a person with 'undetermined citizenship' may be perceived as an 'act of quiet protest against the Estonian state' (Fein, Straughn 2014: 700) whereas granting the citizenship was perceived as a state responsibility (Fein, Straughn 2014: 697). This might serve to explain the lack of determination to go through a naturalization procedure by long-term residents of Estonia. For newly stateless persons that used to feel close ties with the territory of their birth and residence, these procedures, which were not required of their former compatriots, were perceived to be discriminatory. Noteworthy is the fact that even acquisition of

\footnotetext{
${ }^{1}$ Cf. 'ethnic Latvians' by analogy
} 
citizenship did not prevent from a growing social gap between ethnic and nonethnic Estonians (Fein, Straughn 2014: 700).

\section{Role of the EU in addressing the problem of statelessness}

Latvia and Estonia went through the EU integration procedures which required fulfilment of the Copenhagen criteria related to political and economic coherence with the EU standards and the adoption of the acquis communautaire.

\section{Before the accession to the EU}

The case studies share a few common features, such as geopolitical fluctuations in the 1990s, considerable change in economic model that came with it, and participation in the accession process that led to the biggest EU enlargement in 2004. '[A]t the beginning of May 1993, the Commission presented the Member States with a document on the future of EU enlargement containing no references to either the Baltic countries' (Estonian Ministry of Foreign Affairs 2009). Gradually, these states appeared on the EU enlargement agenda, question of statelessness, however, was perceived differently in the context of enlargement.

In Latvia, as Kristīne Krūma argued, 'EU accession negotiations avoided issues related to the status and rights of non-citizens' (Krūma 2014:396). At an early stage, the concerns of the EU were related not to the Latvian law on citizenship, but to the procedure of naturalization. Preceding developments regarding 'remained outstanding the question of a law on citizenship and the definition by law of the rights and status of non-citizens' (Council of Europe 2015: point 4), there were obstacles to the adherence of the Council of Europe (CoE). Although the CoE is not an EU institution, the application of Latvia for membership to the former was an important step on the way to be a part of the EU. The compromise found on the regulations on citizenship, although not completely in line with the OSCE High Commissioner on National Minorities recommendations, was that Latvia became a member of the CoE in 1995 (Vrbek 2015: 311), while taking commitments to consult and cooperate with this institution in questions related to non-citizens (CoE 2015: point 6). Therefore, the momentum of a tangible international influence was lost and the question of statelessness only appeared later.

'Latvia was denied opening accession negotiations in 1998 due to Noncitizens problem' (Vrbek 2015: 303) and the amendments in citizenship law were the main requirement from the EU side. That was the reason for the liberalization of the regulation (Vrbek 2015: 311). However, the issue of statelessness was seen primarily not as a human rights violation, but rather as an obstacle to exercise the main freedoms associated with the EU acquis, in particular, the freedom of movement. That finds confirmation in a fact that during the pre-accession period a suggestion on granting the EU citizenship to the noncitizens was expressed, however did not result into concrete follow-up steps. 
The prospect of such a solution was perceived as a risk for incentives to apply for naturalization and even 'threatened the positive outcome of the accession referendum' (Krūma 2014:444). In the short-term perspective it raised the amount of citizenship applications, nonetheless it was not a sustainable approach (Krūma 2014:444). Notwithstanding the improvement in numbers of applications after liberalization of the law in 1998, the amount of non-citizens before the accession to the EU remained immense - half a million of persons (Vrbek 2015: 311), almost a quarter of population in 2003 (Expansion 2016).

Despite the influence of the EU in the form of supplementary requirements provided for Latvia before the accession related to employment and voting rights, and indirectly addressing the issue of statelessness, the situation of the rights of non-citizens remained disputable. However, certain professions were derestricted; language exam requirements to qualify as a candidate for election were lowered; limitations on receiving social support in justified cases for the ones who did not have knowledge of Latvian were reduced (Vrbek 2015:311). Moreover, 'European conditionality has influenced the transition from nationalism to nation-building' (Galbreath 2006: 403). In 2001 Latvia signed the European Convention on Nationality. Ratification, however did not follow.

Estonia did not experience the same difficulties as Latvia in attaining membership of the CoE and became the $27^{\text {th }}$ member state of the latter in 1993. It would be difficult to estimate the direct influence of this organisation and its tools in addressing the issue of statelessness in Estonia given the ineffectiveness of regional instruments. The latter can be explained due to the lack of enforcing mechanisms and conditionality; whereas the comparison between the position of the EU on the Baltic States from the perspective of the Copenhagen criteria would be possible.

The European Commission's (EC) Agenda 2000 reports - opinions issued in 1997 concerning the Applications for Membership to the European Union presented by the candidate countries - made clear that while in Latvia noncitizens were 'affected by various types of discrimination' (EC 1997), the rights of stateless population in Estonia were safeguarded to a greater degree. Both countries were strongly advised 'to take measures to accelerate naturalisation procedures to enable the Russian-speaking non-citizens to become better integrated' into their societies. Estonia was pictured as a country that 'demonstrates the characteristics of a democracy, with stable institutions guaranteeing the rule of law and human rights', while Latvia had this definition highly dependent on further steps toward improving policies related to non-citizens.

Although the problem of statelessness was acknowledged by the EU and the unwillingness of Estonia to include the protection of persons with undetermined citizenship to the CoE's framework convention on minorities was not perceived as an obstacle to assess the issue of Estonia's non-citizens in the context of enlargement, the wording related to Estonia was more moderate than the one related to Latvia. 
The EU's stronger involvement in the case of Latvia compared to Estonia was dictated by several factors. From a legal perspective, the absence of an endemic legal category of 'non-citizens' was preferable in comparison to Estonia's 'undetermined citizenship' with its creative avoidance of mentioning statelessness. Therefore, in Estonia, the legal status was subjected to a zerosum game: 'undetermined citizenship' or Estonian citizenship, while in the neighbouring Baltic State, the non-citizen status was growing into a continuous one. The other factor was technical: freedom of movement, which was secured by issuing the 'aliens' passports' in Estonia, happened earlier than in Latvia. Moreover, Estonian legislation, unlike the Latvian, did not contain discriminative provisions related to ownership of the land or occupational bans; and naturalization process did not contain a 'window system'. Therefore initially this was less restricted than Latvian as all permanent residents could apply for citizenship. Consequently, from a formal perspective, Estonia was in a better position to address the issue of statelessness and protect fundamental rights than its neighbour, which resulted in imposing less pre-accession requirements by the EU to the former.

\section{After the accession}

As is the case with frozen conflicts and other security issues, the EU inherits problems if it does not resolve them prior to enlargement. The issue of statelessness in Latvia and Estonia was also not resolved. The leverage of the EU on the statelessness issue was subjected to different mechanisms after 2004. While the liberalization of the Latvian law on citizenship in 1998 was possible due to conditionality imposed on an EU candidate state, as soon as Latvia became a member of the EU, the demands were reduced to recommendations. Starting with the resolution of the European Parliament (EP) in March 2004 (EP 2004), the issue of statelessness was mentioned in a context of encouraging the Latvian authorities to address the issue and welcoming the governmental naturalization programme of Estonia. In one case (EC 2006: $110,113)$ the problem was referred as 'new issues [that] have been brought to the fore such as $\langle\ldots\rangle$ situation of stateless persons in certain Member States' without explicitly 'blaming and shaming' the countries in question.

EU citizenship as a 'belonging beyond the state' (Krūma 2014:412) has not been able to play a role in the discourse as it was conditioned by the possession of a citizenship of a member state. The possibility of requesting 'the long-term resident or other immigrant status under relevant directives the EU' (Krūma 2014:366) by non-citizens of the Baltic States was a marginal option: not only because it was not sufficiently communicated, but also because of lack of practical advantages compared to non-citizen status (Krūma 2014:398).

The capability of the EU to impact the issue of statelessness after the accession of Latvia and Estonia might be mostly considered as indirect ones. While stressing the progress in citizenship applications in the Baltic States 
prior to their accession to the EU, and 'condemning' stateless persons in Estonia and Latvia for lack of incentives to go through naturalization procedure because of bilateral agreements with Russia allowing for a free movement; despite formal improvements in legislation, the social gap between non-citizens and the EU citizens was not diminishing. In Latvia, it was expressed in the differences in voting rights or professional limitations. In both countries due to a failure to identify stateless persons, accession to the EU did not resolve the internal challenges that were present before 2004.

In spite of considerable positive amendments in legislation of Estonia related to stateless children in 2002 and in 2015, and the commitment of Latvia to promote naturalization, in both cases to some extent influenced by the EU position, thriteen years after the accession, there were over 85,000 stateless persons in Estonia and over 252, 000 stateless persons in Latvia (ISI 2017: 87, 75).

In the course of time the focus of the EU in areas related to the statelessness issue was dynamic. If before the accession of the Baltic States, emphasis was put on pressuring in order to implement all the necessary provisions to secure the freedom of movement, later on priority was moved to protection of the rights of stateless persons (ISI 2017: 88).

\section{Conclusion}

Statelessness in the EU post-Soviet states is a phenomenon that requires an interdisciplinary approach. With an emerging interest in academia, statelessness is becoming increasingly important in policy-making. Given the complexity of statelessness, it is broadly considered as a consequence, a source, or a catalyst of human rights violations. Nowadays, the EU, with its extensive human rights agenda, has an important role to play in ending statelessness in the EU post-Soviet states and beyond. Despite the jurisprudence of the Court of Justice of the European Union, which indicates that while exercising their sovereign powers in the sphere of citizenship, Member States have an obligation to 'have due regard to European Union Law' (CJEU 2010 C-135/08: para 62) and place nationality matters within the exclusive competences of the Member States. The conditionality imposed on candidate countries suggests that leverage on the issue of statelessness may be more visible abroad: mainly in the countries with European aspirations in neighbouring regions, where national legislation might be strongly influenced.

Case studies of the EU post-Soviet states have shown that, while Latvia had to make changes in the regulations on naturalisation because of non-citizens problem, Estonia having similar percentage of 'persons with undetermined citizenship' was not challenged to the same extent in order to fulfil Copenhagen criteria. The inconsequence of the EU in the question of statelessness does not derive from deliberate double standards, but from the lack of strategy in addressing this issue. The coherence in the EU's actions may be 
found and required in the areas that were explicitly formulated policy documents with a legal basis.

Statelessness in the EU post-Soviet states is a serious human rights concern that was not viewed by the EU as a breach of human rights in Latvia and Estonia. Therefore, EU influence was mostly limited by considerations related to the free movement, and the alignment of legislation of a candidate country to the EU standards was implied by the power of conditionality. Ultimately, both Latvia and Estonia became Member States, and the EU, with such an absorption, inherited statelessness. Requirements were diminished to recommendations and internal role of the EU was somehow weakened in this context. Regardless of the direction of the CJEU case-law in 'injecting' the EU into nationality matters, the pre-accession period should be used more systematically in future enlargement prospects.

The EU with its unique opportunity to tackle human rights issues may use its power for the post-Soviet countries with EU membership aspirations, should the problem of statelessness be recognised as a separate component of a successful accession process. Its actions in the Member States internally depend on questions related to the acquis and by consequence do not target statelessness per se. By transmitting to the acquis the notions explicitly targeting statelessness, the EU might become directly accountable for addressing this issue and, therefore, more efficient. The transitional period between 'externality' and 'internality' of the problem achieved by accession to the EU of the new Member States should be treated through the prism of statelessness and its possible implications. Following UNHCR's idealistic ambition to end statelessness by 2024 (UNHCR 2014), there is a hope that in less than a decade the present work would be an obsolete analysis of a non-existent phenomenon. To reach this desirable state of affairs, stronger and more systematic engagement on the part of the EU is indispensable.

\section{References}

Cahn C. (2012) Minorities, Citizenship and Stateless in Europe, European Journal on Migration and Law, 14 (3): 297-316.

Costamagna F. (2013) Statelessness in the Context of State Succession. A. Annoni, S. Forliati (eds.) The Changing Role of Nationality in International Law. London and New York: Routledge Research in International Law:37-53.

(CoE) Council of Europe (2000) European Convention on Nationality, ETS No. 166. Available at: https://rm.coe.int/168007f2c8 (accessed 17 January 2018).

CoE, Parliamentary Assembly (1995) Application by Latvia for Membership of the Council of Europe, Opinion 183. Available at: http://assembly.coe.int/nw/xml/XRef/Xref-XML2HTML-en.asp?fileid=13922\&lang=en (accessed 17 January 2018). 
Court of Justice of the European Union (2010) Rottmann v Freistaat Bayern, Case C-135/08, 2 March 2010, para 62. Available at: https://eur-lex.europa.eu/legal-content/EN/TXT/ ?uri=CELEX\%3A62008CJ0135 (accessed 17 January 2018).

Estonian Ministry of Foreign Affairs (2009) Estonia's Way into European Union. Available at: http://www.vm.ee/sites/default/files/content-editors/web-static/052/Estonias_way_into the_EU.pdf (accessed 17 January 2018).

European Commission (1997) Agenda 2000 - Commission Opinion on Latvia's Application for Membership of the European Union, DOC 97/14 (political criteria, general evaluation). Available at: http://europa.eu/rapid/press-release_DOC-97-14_en.pdf (accessed 17 January 2018).

European Commission (2006) Enlargement, Two Years After: An Economic Evaluation by the Bureau of European Policy Advisers and the Directorate-General for Economic and Financial Affairs, Occasional Papers, No 24. Available at: http://ec.europa.eu/economy_finance/publications/pages/publication7548_en.pdf (accessed 17 January 2018).

European Network on Statelessness (2015) Ending Childhood Statelessness: A Study of Estonia, working paper 04/15. Available at: http://www.statelessness.eu/sites/www.statelessness.eu/files/Estonia.pdf_(accessed 17 January 2018).

European Parliament (2004) Resolution on the Comprehensive Monitoring Report of the European Commission on the State of Preparedness for EU Membership of the Czech Republic, Estonia, Cyprus, Latvia, Lithuania, Hungary, Malta, Poland, Slovenia and Slovakia, P5_TA(2004)0180. Strasbourg.

European Parliament (2018) Human Rights. Fact Sheets on the European Union. Available at: http://www.europarl.europa.eu/factsheets/en/sheet/165/human-rights_(accessed 25 November 2018).

Crampton P. (1999) Democratic Rights in Estonia. Official Journal of the European Communities Information and Notices, 41 (18): 108.

Neachtain S. Ó (2004) Written Question P-0770/04 by EU citizenship. Official Journal of the European Communities Information and Notices, 3 (4):671-672.

Expansion (2016) Population of Latvia goes up. Available at: http://countryeconomy.com/ demography/population/latvia (accessed 17 January 2018).

Fein L. C., Straughn J. B. (2014) How Citizenship Matters: Narratives of Stateless and Citizenship Choice in Estonia. Citizenship Studies 18 (6-7): 690-706.

Foster M., Lambert H. (2016) Statelessness as a Human Rights Issue: A Concept Whose Time Has Come. International Journal of Refugee Law, 28 (4): 564-584.

Gelazis N. M. (2004) The European Union and the Statelessness Problem in the Baltic States. European Journal of Migration and Law, 6 (3):225-242.

Galbreath D. J. (2006) From Nationalism to Nation-Building: Latvian Politics and Minority Policy. Nationalities Papers, 34 (4):383-406.

Gyulai G. (2012) Statelessness in the EU Framework for International Protection. European Journal of Migration and Law, 14 (3): 279-295.

Human Rights Watch (2017) World Report 2017 (events of 2016). Available at: https://www.hrw. org/sites/default/files/world_report_download/wr2017-web.pdf (accessed 17 January 2018). 
Iogna-Prat M. (2016) Nationality and Statelessness Issues in the Newly Independent States. V. Gowlland-Debbas (ed.) The problem of Refugees in the Light of Contemporary International Law. The Hague: Kluwer Law International:25-34.

(ISI) Institute on Statelessness and Inclusion (2014) The World's Stateless. Available at: http://www.institutesi.org/worldsstateless.pdf (accessed 17 January 2018).

(ISI) Institute on Statelessness and Inclusion (2017) The World's Stateless Children. Available at: http://www.institutesi.org/worldsstateless17.pdf(accessed 17 January 2018).

Judgement on behalf of the Republic of Latvia, Riga, 17 February 2011, Case No. 2010 20-0106, par. 13, available at: http://www.satv.tiesa.gov.lv/wp-content/uploads/2010/03/ 2010-20-0106_Spriedums_ENG.pdf (accessed 17 January 2018).

Krūma K. (2014) EU Citizenship, Nationality and Migrant Status an Ongoing Challenge. J. Niessen, E. Guild (eds) Immigration and Asylum Law and Policy in Europe. Leiden: Martinus Nijhoff Publishers: 1-498.

Latvian Human Rights Committee (2013) List of Differences in Rights between Latvian Citizens and Non-citizens of Latvia, Riga. Available at: http://www.lhrc.lv/biblioteka/svod_razl_2013 rus.pdf (accessed 17 January 2018).

Law of Republic of Latvia (1995) On the Status of those Former U. S.S.R. Citizens who do not have the Citizenship of Latvia or that of any Other State; adopted by the Saeima on 12 April 1995, unofficial translation of the CoE. Available at: http://www.coe.int/t/dghl/ standardsetting/nationality/National\%20legislation/Latvia\%20-\%20Law\%20on\%20noncitizens.pdf (accessed 17 January 2018).

Manly M., Van Waas L. (2014) The State of Statelessness Research. A human Rights Imperative. Tilburg Law Review, 19 (1-2):3-10.

Manners I. (2002), Normative Power Europe: A Contradiction in Terms? Journal of Common Market Studies, 40 (2):235-258.

Miljan T. (2015) Historical Dictionary of Estonia. Maryland: Rowman \& Littlefield

Morris H. (2003) EU Enlargement and Latvian Citizenship Policy. Journal on Ethnopolitics and Minority Issues in Europe, 1 (1) 2003: 1-37.

Muiznieks N., Rozenvalds J., Birka I. (2013) Ethnicity and Social Cohesion in the PostSoviet Baltic States. Patterns of Prejudice, 47 (3): 288-308.

Nye J.S. (2004) Soft Power: The Means to Success in World Politics. Public Affairs, New York.

Parliament of Estonia (2016) Restoration of the Independence of Estonia. Available at: https://www.riigikogu.ee/ru/glavnye-temy-ru/vosstanovlenie-nezavisimosti-estonii-1991-g/ (accessed 17 January 2018).

Sasse G. (2008) The Politics of EU Conditionality: The Norm of Minority Protection during and Beyond EU Accession. Journal of European Public Policy, 15 (6): 842-860.

Simonian R. (2004) The Russian Diaspora in the Baltic Countries. Russian Politics \& Law, 42 (4): 67-88. 
Snyder F. (ed.) (2000) The Europeanisation of Law: The Legal Effects of European Integration. Studies in European Law and Integration, European Law Series Oxford/Portland, Hart Publishing.

Tucker J (2014) Questioning de facto Statelessness by Looking at de facto Citizenship. Tilburg Law Review, 19 (1-2): 277.

United Nations High Commissioner for Refugees (2014) Global Action Plan to End Statelessness. Available at: http://www.unhcr.org/protection/statelessness/54621bf49/global-action-plan-end-statelessness-2014-2024.html (accessed 17 January 2018).

United Nations (1961) Convention on the Reduction of Statelessness. UN, Treaty Series, vol. 989 , p. 175.

United Nations (1954) Convention Relating to the Status of Stateless Persons. UN, Treaty Series, vol. 360, p.117.

Vetik R. (2011) The Statelessness Issue in Estonia. C. Sawyer, B. K. Blitz (eds.) Statelessness in the European Union. Displaced, Undocumented, Unwanted. Cambridge: Cambridge University Press: 231-235.

Vrbek S. (2015) Reasons for EU Double Standards: Comparative Overview of the Cases of the Erased and the Non-citizens. Nationality Papers - The Journal of Nationalism and Ethnicity, 43 (2): 302-316.

Zmiyenko O. (2017) The European Union: Power(less) in Statelessness? College of Europe, Natolin Campus: 1-69. 